\title{
Hybrid Dental Composites Biomechanical Properties
}

\author{
CLAUDIA NICOLETA FEURDEAN ${ }^{1 \#, ~ A N I D A-M A R I A ~ B A B T A N ~}{ }^{1 \#, ~ A N C A ~ I O N E L ~}{ }^{1}$, \\ ARANKA ILEA ${ }^{1}$, DAN BUHATEL ${ }^{1}$, ARIN SAVA ${ }^{1}$, MARIOARA MOLDOVAN ${ }^{2 *}$, \\ CODRUTA SAROSI ${ }^{2}$, STEFAN VESA ${ }^{3}$, RADU SEPTIMIU CAMPIAN ${ }^{1}$ \\ ${ }^{1}$ Iuliu Hațieganu University, Faculty of Dentistry, Oral Rehabilitation Department, 15 Babes Str., 400012, Cluj-Napoca, \\ Romania \\ ${ }^{2}$ Raluca Rîpan Chemistry Institute, 15 Fântânele Str., 400620, Cluj-Napoca, Romania \\ ${ }^{3}$ Iuliu Hațieganu University, Faculty of Medicine, Pharmacology Department, 23 Marinescu Str., 400337, Cluj-Napoca, \\ Romania
}

Abstract: In the last two decades, both general and oral health status became more important for individuals, being associated to their quality of life, social provenance and income. Society's evolution is associated to high expectations regarding edentulous and decays treatment. Metal filling such as gaudent or amalgam have been replaced by aesthetic materials, to achieve similarity to the patient's genuine biological tissue. Along with the aesthetic demand, dental materials have to fulfill biocompatibility and mechanical properties proximate to healthy soft either hard tissues. Composite materials have the advantages of accomplishing biological and mechanical demands and to be accessible financially, compared to ceramics. Composites are classified according to the main monomer, filling, particles' dimension, addition of external molecules, this entirety having a direct influence on materials' properties. The objective of this prospective interventional in vitro study was to evaluate biomechanical properties of four different hybrid composites: Premise direct ${ }^{\mathrm{TM}}$ - Premise indirect $^{\mathrm{TM}}$ (Kerr, Orange, California, USA), Gradia ${ }^{\circledR}$ Direct (GC, Alsip, Illinois, USA) and Ceramage ${ }^{\circledR}$ (SHOFU Dental, Ratinger, Germany). Vickers microhardness, compressive strenght, direct tensile strenght, water absorption and solubility were assessed. The results showed that microfilled hybrid composites UDMA (urethane dimethacrylate)-based monomer had the highest evaluations regarding Vickers microhardness, compressive strenght and tensile strenght, whereas water absorption was the highest for nanofilled hybrid Bis-GMA (bisphenol A-glycidyl methacrylate)/TEGDMA (triethylene glycol dimethacrylate), and solubility for microfilled hybrid UDMA based monomer.

Keywords: composite, hybrid filler, biomechanical properties, dental restoration

\section{Introduction}

Along with the Minamata agreement regarding discontinuation of amalgam fillings in dentistry, resin-based materials were developed, especially for the posterior area [1]. Filling materials are subdued to physicochemical forces (temperature oscillation, salivary enzymes, bacteria metabolites), which differ from a patient to another [2]. This beginning of a new era of resin composites with a low molecule's dimension, gives the dentists the opportunity to perform dental filling which are mechanical superior, along with an esthetic similar to natural teeth (the small particles give the chameleon-like properties and light reflection) [3]. Although there is a large possibility of choices regarding restoration dental materials, hybrid composites have a similar structure, with a low hardness organic matrix and a high hardness non-organic matrix (ceramics usually). Along with the per se composite materials components by its two phases (organic and non-organic), the monomer's hydrophilic character contributes to the degradation process.

The fillers have been developed in order to reduce material viscosity and to increase the esthetics, handling and degree of polishing; in association with the fillers, producers include precured resins (reduce the curing contraction), with let a higher filler concentration loading [4]. Through this hybrid materials, dental materials suppliers try to obtain the highest filler concentration, with the lowest molecular dimension, in order to reduce intermolecular tension and to benefit of its advantages [5]. 
Hybrid composites have in their chemical composition an non-organic reinforced polymer matrix, which represents $60 \%$ or more from the whole volume, made by fiberglass (with a $0.6-1 \mu \mathrm{m}$ particle dimension variation), and colloidal silica $(0.04 \mu \mathrm{m}$ particle dimension) [6]. The hybrid material's characteristics are represented by a large color choice which copies dental structure, have a low water absorption, thermic expansion coefficient resemblance to natural teeth, various degrees of opacity and translucence, the same composition for both anterior and posterior reconstruction, without affecting their mechanical properties [7].

Trimodal hybrid nanofilled composites, such as Premise direct ${ }^{\mathrm{TM}}$, Premise indirect ${ }^{\mathrm{TM}}$ (Kerr, Orange, California, USA) are indicated in frontal and lateral esthetic dental restoration, due to the three type of filler (silica $0.02 \mu \mathrm{m}$ particles, $0.4 \mu \mathrm{m}$ barium silicate particles and precured fillers), which give an easy handling, improved mechanical properties and a higher polishing degree to the materials, esthetic consideration which make difficult to detect filling-enamel junction [8]. Hybrid microfilled materials Gradia ${ }^{\circledR}$ Direct (GC, Alsip, Illinois, USA) either Ceramage ${ }^{\circledR}$ (SHOFU Dental, Ratinger, Germany) have silica dioxide, zirconium silica, fluor-alluminium-silicate fiberglass, which associate mechanics with the cvasinatural copying of the dental surface color, and the mechanical properties of Ceramage ${ }^{\circledR}$ extend its indication in implant prosthetic overdentures [9].

The objective of the present prospective interventional study was to compare biomechanical properties in microfilled and nanofilled hybrid dental composites.

\section{Materials and methods}

We used four dental restoration hybrid composites (Table 1) [10]:

- two hybrids with nanofilling (Premise direct ${ }^{\mathrm{TM}}$, Kerr, Orange, California, USA and Premise indirect $^{\mathrm{TM}}$, Kerr, Orange, California, USA)

- two hybrids with microfilling (Gradia ${ }^{\circledR}$, GC, Alsip, Illinois, USA and Ceramage ${ }^{\circledR}$, SHOFU Dental, Ratinger, Germany).

Table 1. Hybrid composite material characteristics

\begin{tabular}{|c|c|c|c|c|c|c|}
\hline Composite & Type & Manufacture & Resin & Filling & $\begin{array}{l}\text { Filling } \\
(\%)\end{array}$ & $\begin{array}{c}\text { Particle } \\
\text { dimension }\end{array}$ \\
\hline $\begin{array}{l}\text { Premise di- } \\
\text { rect }^{\text {TM }}\end{array}$ & $\begin{array}{l}\text { Trimodal nan- } \\
\text { ofilled }\end{array}$ & $\begin{array}{l}\text { Kerr, Orange, } \\
\text { Califormia, USA }\end{array}$ & $\begin{array}{l}\text { Bis-GMA, } \\
\text { TEGDMA }\end{array}$ & $\begin{array}{l}\text { Silica, barium fiberglass sil- } \\
\text { icate, precured filler }\end{array}$ & $\begin{array}{c}70 \%, 84 \\
\text { wt } \%\end{array}$ & $\begin{array}{c}30-50 \mu \mathrm{m} \\
\text { (filler) } \\
0.04 \mu \mathrm{m} \text { (bar- } \\
\text { ium silicate) } \\
0.4 \mu \mathrm{m} \text { (silica) }\end{array}$ \\
\hline $\begin{array}{c}\text { Premise } \\
\text { indirect }^{\mathrm{TM}}\end{array}$ & $\begin{array}{l}\text { Trimodal nan- } \\
\text { ofilled }\end{array}$ & $\begin{array}{c}\text { Kerr, Orange, } \\
\text { California, USA }\end{array}$ & $\begin{array}{l}\text { Bis-GMA, } \\
\text { TEGDMA }\end{array}$ & $\begin{array}{l}\text { Fiberglass, barium silicate, } \\
\text { hybrid silica, precured filler }\end{array}$ & $\begin{array}{l}72 \%, \\
87 w t \%\end{array}$ & $0.02-50 \mu \mathrm{m}$ \\
\hline Gradia $^{\Phi}$ & Microfilled & $\begin{array}{l}\text { GC, Alsip, Illinois, } \\
\text { USA }\end{array}$ & UDMA & $\begin{array}{l}\text { Precured filler, silica diox- } \\
\text { ide }\end{array}$ & $\begin{array}{c}75 \% \text { wt, } \\
65 \%\end{array}$ & $0,85 \mu \mathrm{m}$ \\
\hline Ceramage $^{\oplus}$ & Microfilled & $\begin{array}{l}\text { SHOFU Dental, Rat- } \\
\text { inger, Germany }\end{array}$ & UDMA & Zirconium silicate & $73 \%$ wt & $\mathrm{VN}$ \\
\hline
\end{tabular}

Legend: Bis-GMA - bisphenol A-glycidyl methacrylate; TEGDMA - Triethylene glycol dimethacrylate; UDMA - urethane dimethacrylate; VN- value not known.

The following properties were evaluated: Vickers microhardness (HV), Compressive strenght (CS), direct tensile strenght (DTS), water absorption $\left(\mathrm{W}_{\mathrm{sp}}\right)$, water degradation (SL).

\subsection{HV evaluation}

A device (Carl Zeiss Jena, Germania) connected to a Neophot 21 microscope was used to cuantum the microhardness $(0.5 \%$ precision). The composite samples (Figure $1 \mathrm{~A}, 1 \mathrm{~B})$ were manufactured by light-curing under a cylindrical $(3 \mathrm{~mm}$ height, $6 \mathrm{~mm}$ diameter) glass mould (provides the flatness and shining of the sample's surface). The composite material was light-cured for $180 \mathrm{~s}$ with a Woodpecker 
lamp (Guilin Woodpecker Medical Instrument Co Ltd, PR China). The samples were taken out from the mould and inserted in a thermo-baro medium, for $20 \mathrm{~min}$, at $139{ }^{\circ} \mathrm{C}$ and 60 psi pressure.

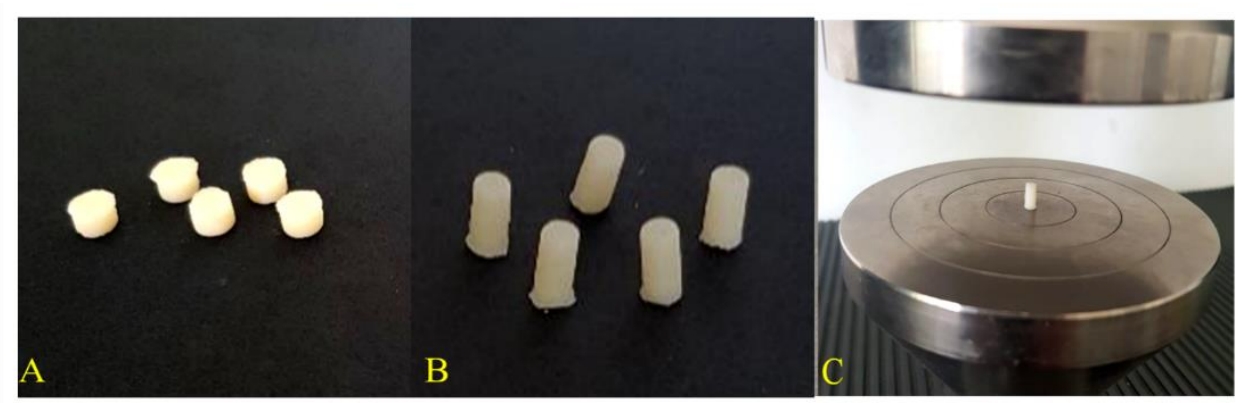

Figure 1. Standard composite samples (A, B); HV testing device (C)

HV was performed according to 6300-64 STAS standard. Composite samples went under a F=20 gf force (Figure 1C). The penetrative part of the device had a $20 \mu \mathrm{m} / \mathrm{s}$ speed, perpendicular on the composite surface, for a duration of $15 \mathrm{~s}$, after it has been brought the matrix intersection point, so that it matches the shadows' square corner. Using the ocular centring screw, the shadow was enclosed, and corresponding divisions were read $(1$ division $=0,36 \mu \mathrm{m})$, from which $\mathrm{d}=\mathrm{div} \times \mathrm{x} 0.36$ diagonal was calculated using the following formula (1):

Vickers microhardness= loading charge/shadow area,

$$
H V=\frac{1854,4 \cdot F}{d^{2}}
$$

for F (gf), d - mean indenter diagonal length (mm), F (kgf).

\subsection{CS evaluation}

CS was determined according to ISO 4049/2002 standard. A teflon mould (8 mm diameter) which incorporates a cylindrical cavity ( $3 \mathrm{~mm}$ diameter and $6 \mathrm{~mm}$ height) was used, in which the four categories of composite were alternately introduced, producing standard composite samples. The composite material was brought out from the mould and light-cured for $180 \mathrm{~s}$ with a Woodpecker (Guilin Woodpecker Medical Instrument Co Ltd, PR China) lamp. After 3 min from the curing stage, composite samples were introduced in water medium $-15 \mathrm{~min}$ at $37 \pm 1^{\circ} \mathrm{C}$, and after in distilled water. After $23 \mathrm{~h}$, composite samples were measured with a micrometer and reinserted for the second time in distilled water for $50 \mathrm{~h}$. CS was evaluated by introducing the samples in a mechanical testing device (LLOYD LR5K Plus, LLOYD, Ametek@ testing Instruments, Shanghai, China), which electronically measures the samples' diameter and F force recorded at the moment of composite fracture, and CS (MPa) using the formula (2):

$$
R C=F / \pi r^{2}
$$

where $\mathrm{F}$ - composite fracture moment recorded force, $\mathrm{r}$ - samples' range (recorded before the testing).

There were 5 to 10 evaluation per sample and CS was their mean. Samples which had a $15 \%$ different value from the lot were not considered, and more than two specimens with a more than $15 \%$ difference lead to the repeat of the evaluation for the entire lot.

\subsection{DTS evaluation}

DTS was assessed according to ADA (American Dental Association), specification 27 standard Resin-Based Filling Materials [11], as follows: we used diametral compression test on the composite samples' long axis. A teflon mould (8 mm diameter) which incorporates a cylindrical cavity $(6 \mathrm{~mm}$ diameter, $3 \mathrm{~mm}$ height) was used, in which the four categories of composite were alternately introduced, 
producing standard composite samples (Figure 1B). After removing the samples from the mould, the samples were light-cured using a Woodpecker (Guilin Woodpecker Medical Instrument Co Ltd, PR China) lamp and introduced in a thermo-baro oven, for $20 \mathrm{~min}$ at $139^{\circ} \mathrm{C}$ and 60 psi pressure. Composite samples were immersed in distilled water for $23 \mathrm{~h}$, at $37^{\circ} \mathrm{C}$. DTS test was performed by applying a force between the devices' plates (which incorporate the sample) and generate vertical tensile strenght. DTS (MPa) was quantified using the formula (3):

$$
R T=2 \times F / \pi \times D \times T
$$

where $\mathrm{F}$ - the composite fracture moment recorded force $(\mathrm{N})$; D - samples' diameter $(\mathrm{mm})$; $\mathrm{T}$ - samples' thickness (mm).

\subsection{Composite Wsp and SL evaluation}

Water absorption and solubility were assessed according to ADA, specification 27 standard - ResinBased Filling Materials [11], as follows: a teflon mould was used to obtain the composite samples (15 mm diameter, $1 \mathrm{~mm}$ thickness) - disc shape (Figure 1A) cured for $20 \mathrm{~s}$ on each side. After the composite probes were removed from the mould, they were dried in $\mathrm{CaCl}_{2}$ medium, at $37 \pm 1^{\circ} \mathrm{C}$ temperature. The disc-shaped samples were scaled and immersed in distilled water for 30 days. The determinations were performed at 1, 4, 6, 7, 8 and 31 days. Before each evaluation stage, the samples were air-dried for $15 \mathrm{~s}$. Absorption $\left(\mathrm{W}_{\mathrm{sp}}\right)$ was calculated using the formula (4):

$$
W s p=(m 2-m 3) / V
$$

where m2 - samples' weight $(\mu \mathrm{g})$ after water immersion; $\mathrm{m} 3$ - samples' weight reconditioned $(\mu \mathrm{g})$; V samples' volume $\left(\mathrm{mm}^{3}\right)$.

The protocol was the same for SL determination $\left(\mu \mathrm{g} / \mathrm{mm}^{3}\right)$ and the evaluations were performed at 1 , $4,6,7,8$, and 31 days. SL was quantified using the formula (4):

$$
S L=(m 1-m 3) / V
$$

where $\mathrm{m} 1$ - samples' weight $(\mu \mathrm{g})$ before water immersion; $\mathrm{m} 3$ - samples' weight held in an exicator until a constant weight is obtained $(\mu \mathrm{g}), \mathrm{V}$ - samples' volume (în $\mathrm{mm}^{3}$ )

\subsection{Statistical analysis}

Statistical analysis was performed using the MedCalc Statistical Software version 19.2.1 (MedCalc Software Ltd, Ostend, Belgium; https://www.medcalc.org; 2020). Quantitative variables were tested for normality of distribution using the Shapiro-Wilk test and were expressed as mean \pm standard deviation. Comparisons between groups were performed using the ANOVA test, with Tukey post-hoc test. Comparisons between repeated measurements were performed using two-way ANOVA for repeated measures. Correlations between variables were tested using Pearson correlation. The $p$ value $<0.05$ was considered statistically significant.

\section{Results and discussions}

The study's objective was to evaluate mechanical properties of bulk-fill hybrid composite available on the market, which present variation in dimension and particles' loading. Producers allege that introducing nanoparticles in composite enhances the increase of filler material percentage and implicitly stress endurance without affecting the viscosity [12]. Giving the fact that in oral cavity dental materials undergo $p \mathrm{H}$ alterations, biofluid, diet and beverages, the abrasion degree caused by teethbrushing either parafunctions, in vitro studies don't manage to reproduce these conditions in laboratories, and the properties might be not entirely correct [13].

\subsection{HV}

The results in HV assessment are presented in Table 2. The highest d value was identified for Gradia ${ }^{\circledR}$ composite, followed by Premise Indirect, Premise Direct and Ceramage ${ }^{\circledR}$. Regarding microhardness, the 
highest HV value was for Ceramage ${ }^{\circledR}$ and the lowest for Gradia ${ }^{\circledR}$, as follows: 155.246 (Ceramage $\left.^{\circledR}\right)>$ 126.204 (Premise indirect $^{\mathrm{TM}}$ )> 121.412 (Premise direct $^{\mathrm{TM}}$ )> 77.629 (Gradia).

Table 2. Composite HV-mean and standard deviaion (SD)

\begin{tabular}{|c|c|c|}
\hline Variable Mean \pm (SD) & HV [dN/mm2] & d \\
\hline Gradia $^{\mathbf{\Phi}}$ & & $0.2167 \pm 0.000692$ \\
\hline Ceramage $^{\boldsymbol{\Phi}}$ & $17.629 \pm 4.8844$ & $0.01533 \pm 0.0006$ \\
\hline Premise direct $^{\text {TM }}$ & $121.412 \pm 11.346$ & $0.01735 \pm 0.0004$ \\
\hline Premise indirect $^{\text {TM }}$ & $126.2045 \pm 6.881$ & $0.01783 \pm 0.00046$ \\
\hline
\end{tabular}

Statistical analysis showed significant differences between the four composite groups per property $(\mathrm{p}<0.001)$. D analysis showed a significant difference between Gradia $^{\circledR}$ and the rest of the composites. Ceramage ${ }^{\circledR}$ had a statistically significant higher $d$ values than Premise direct ${ }^{\mathrm{TM}}$ and Premise indirect ${ }^{\mathrm{TM}}$ ( $\mathrm{p}=0.001 ; \mathrm{p}=0.005$, respectively). There was no significant difference between Premise direct ${ }^{\mathrm{TM}}$ and Premise indirect ${ }^{\mathrm{TM}}(\mathrm{p}=0.815)$.

There were highly significant differences between the $\mathrm{D}^{2}$ values in Gradia ${ }^{\circledR}$ group and the rest of groups $(\mathrm{p}<0.001)$. $\mathrm{D}^{2}$ Ceramage ${ }^{\circledR}$ was significantly higher $(\mathrm{p}=0.002)$ compared to Premise direct $^{\mathrm{TM}}$. There was no difference regarding $\mathrm{d}^{2}$ between Ceramage ${ }^{\circledR}$ and Premise indirect $(\mathrm{p}=0,012)$. There was no significant difference between Premise direct ${ }^{\mathrm{TM}}$ and Premise indirect ${ }^{\mathrm{TM}}(\mathrm{p}=0.829)$.

HV had the lowest value in Gradia ${ }^{\circledR}$ composite, which was statistically significant compared to the other materials $(\mathrm{p}<0.001)$. Ceramage ${ }^{\circledR}$ had the highest HV value, which were highly statistically significant compared to Gradia $^{\circledR}$ and Premise direct ${ }^{\mathrm{TM}}(\mathrm{p}<0.001)$, and statistically significant compared to Premise indirect ${ }^{\mathrm{TM}}(\mathrm{p}=0.002)$. There was no difference between Premise direct ${ }^{\mathrm{TM}}$ and Premise indirect $^{\mathrm{TM}}(\mathrm{p}=0.855)$. Researchers applied various methods in HV evaluation - Vickers, Knoop, Barcoll, from which Vickers technique has an easy applicability, because the diamond-shaped indenter does not suffer time-deformation [14]. Vickers microhardness is used in composite resin polymerization degree assessment, and in can be influenced by monomer and filler type, curing-time and lamp angulation [15]. A material with a high filler percentage has increased strength, hardness, and tensile resistance, and will endure more easily oral cavity structures' forces, especially for posterior teeth fillings [4].

In our study, we found high significant differences in all evaluated properties. The composite with the highest HV was Ceramage ${ }^{\circledR}$ (73\% filling), followed by Premise indirect ${ }^{\mathrm{TM}}(84 \%)$, Premise direct $^{\mathrm{TM}}$ $(70 \%)$ and Gradia $^{\circledR}(75 \%)$, with a direct high intensity correlation $(\mathrm{p}<0.001)$ between Gradia ${ }^{\circledR}$ and the rest of the materials. Although regarding de filling degree Ceramage ${ }^{\circledR}$ was the second, it had twice the hardness compared to the results of Engelhardt and $c o$ and Buruiana and $c o$. [16, 17]. One explanation could be the composites' structure - aliphatic UDMA monomer with a higher polymerization degree, flexural and strenght module compared to conventional monomers - TEGDMA (high solubility) [19]. Although having as main monomers Bis-GMA and TEGDMA, Premise indirect and Premise direct had a higher HV because of the precured fibers, which compensate mechanical properties and reduce the post-curing contraction [20]. The statistically significant difference between Gradia ${ }^{\circledR}$ and the other composites could be due to the fact that Gradia ${ }^{\circledR}$ does not have silica particles, which achieve stable and solid bondings [21]. Although it's a microfilled hybrid composite, Gradia ${ }^{\circledR}$ showed a approximately $50 \%$ lower HV value compared cu Ceramage ${ }^{\circledR}$; our results disagree the ones obtained by Rastelli, Kyo-Han and Nascimento, which showed that microfilled composites have a higher hardness compared to nanofilled composited [14, 22, 23]. Premise ${ }^{\mathrm{TM}}$ composite have a similar filling with X-tra Fil (Voco GnbH, Germany) or Filtek (3M ESPE, Dental Production Division, MN, USA), but because of adding the precured filler, Premise's HV was 30\% higher [23, 24].

\subsection{CS}

Values for CS assessment are shown in Table 3. Samples had similar values in diameter, and a ranging from $0.96 \pm 0.307 \mathrm{KN}$ for Premise indirect ${ }^{\mathrm{TM}}$ to $1.687 \pm 0.314$ for Ceramage ${ }^{\circledR}$ of fracture 
strength. CS value was the highest in Ceramage ${ }^{\circledR}$ composite, followed by Premise direct ${ }^{\mathrm{TM}}$, Premise indirect $^{\mathrm{TM}}$ and Gradia ${ }^{\circledR}$.

Table 3. Composite CS value - mean and SD

\begin{tabular}{|c|c|c|c|c|c|c|c|c|c|c|c|c|}
\hline \multirow[t]{2}{*}{$\begin{array}{c}\text { Varia- } \\
\text { ble }\end{array}$} & \multicolumn{3}{|c|}{ Ceramage $^{\Phi}(\mathrm{N}=10)$} & \multicolumn{3}{|c|}{$\begin{array}{c}\text { Premise indirect }{ }^{\mathrm{TM}} \\
(\mathrm{N}=10)\end{array}$} & \multicolumn{3}{|c|}{$\operatorname{Gradia}^{\Phi}(\mathrm{N}=8)$} & \multicolumn{3}{|c|}{ Premise direct $^{\mathrm{TM}}(\mathrm{N}=7)$} \\
\hline & $\begin{array}{c}\text { Diame- } \\
\text { ter } \\
(\mathrm{mm})\end{array}$ & $\begin{array}{c}\text { Break } \\
\text { out } \\
\text { force } \\
(\mathrm{KN})\end{array}$ & $\begin{array}{c}\mathrm{CS} \\
(\mathrm{MPa})\end{array}$ & $\begin{array}{l}\text { Diam- } \\
\text { eter } \\
(\mathrm{mm})\end{array}$ & $\begin{array}{c}\text { Break } \\
\text { out } \\
\text { force } \\
(\mathrm{KN})\end{array}$ & $\begin{array}{c}\mathrm{CS} \\
(\mathrm{MPa})\end{array}$ & $\begin{array}{l}\text { Diam- } \\
\text { eter } \\
(\mathrm{mm})\end{array}$ & $\begin{array}{l}\text { Break } \\
\text { out } \\
\text { force } \\
(\mathrm{KN})\end{array}$ & $\begin{array}{c}\mathrm{CS} \\
(\mathrm{MPa})\end{array}$ & $\begin{array}{l}\text { Diam- } \\
\text { eter } \\
(\mathrm{mm})\end{array}$ & $\begin{array}{l}\text { Breakout } \\
\text { force } \\
\text { (KN) }\end{array}$ & $\begin{array}{c}\mathrm{CS} \\
(\mathrm{MPa})\end{array}$ \\
\hline & $\begin{array}{c}2.98 \\
\pm \\
0.3127\end{array}$ & $\begin{array}{c}1.687 \\
\pm \\
0.314\end{array}$ & $\begin{array}{c}241.635 \\
\pm \\
42.614\end{array}$ & $\begin{array}{c}2.979 \\
\pm \\
0.023\end{array}$ & $\begin{array}{c}0.96 \\
\pm \\
0.307\end{array}$ & $\begin{array}{c} \pm \\
19.928\end{array}$ & $\begin{array}{c}3.021 \\
\pm \\
0.022\end{array}$ & $\begin{array}{c}1.531 \\
\pm \\
0.204\end{array}$ & 29.434 & $\begin{array}{c}3.008 \\
\pm \\
0.03\end{array}$ & $\begin{array}{c}1.462 \\
\pm \\
0.227\end{array}$ & $\begin{array}{c}220.174 \\
\pm \\
19.643\end{array}$ \\
\hline
\end{tabular}

There was no significant difference in samples' diameter in the four tested groups. Ceramage ${ }^{\circledR}$ 's breakout force had a high intensity significant correlation compared to Premise indirect ${ }^{\mathrm{TM}}(\mathrm{p}<0.001)$. There was no difference between Ceramage ${ }^{\circledR}$ and Gradia ${ }^{\circledR}$ or Premise direct ${ }^{\mathrm{TM}}$. There was a significant difference $(\mathrm{p}=0.004)$ between Premise indirect ${ }^{\mathrm{TM}}$ and Premise $\operatorname{direct}^{\mathrm{TM}}(\mathrm{p}=0.004)$ and with Gradia ${ }^{\circledR}$ $(\mathrm{p}=0.001)$. CS was not statistically significant different in any of the tested materials.

CS had the highest value in microfilled Ceramage ${ }^{\circledR}$ material, followed by nanofilled and Gradia ${ }^{\circledR}$. Regarding CS, adding Bis-GMA, TEGDMA, silica, as they are in Premise ${ }^{\mathrm{TM}}$ composites, leads to a superior strenght [26]. Alkhudhairy and Vohra comparatively evaluated CS in $\mathrm{Zr}$ and non-Zr filler (>70\% of the volume) [27]. His results were similar to ours, his findings regarding CS being proximate to Ceramage ${ }^{\circledR}$, which also has $\mathrm{Zr}$ silica in the non-organic matrix. Moreover, he noticed that by increasing the curing time, CS is highly improved. For both DTS and CS we noticed that the strength was significantly higher in UDMA organic matrix and $\mathrm{Zr}$ silica, which is superior to nanofilling and precured fillers.

\subsection{DTS evaluation}

Values regarding DTS assessment are shown in Table 4. DTS had a $36.5 \pm 6.532 \mathrm{MPa}$ mean, the highest value being recorded for Ceramage ${ }^{\circledR}$ composite, followed by Premise indirect ${ }^{\mathrm{TM}}$, Premise direct $^{\mathrm{TM}}$ and Gradia ${ }^{\circledR}$. There were no significant differences for DTS in the four composite categories.

Table 4. DTS evaluation - mean and DS

\begin{tabular}{|c|c|c|c|c|}
\hline \multirow{2}{*}{ Variable (N=5) } & \multicolumn{3}{|c|}{ DTS - Mean \pm SD } \\
\hline & D (mm) & H (mm) & Breakout force (KN) & DTS (MPa) \\
\hline Gradia $^{\mathbf{\Phi}}$ & $6.128 \pm 0.017$ & $3.036 \pm 0.056$ & $0.993 \pm 0.204$ & $33.968 \pm 6.784$ \\
\hline Ceramage $^{\boldsymbol{\Phi}}$ & $6.166 \pm 0.049$ & $3.108 \pm 0.118$ & $1.184 \pm 0.184$ & $39.210 \pm 4.454$ \\
\hline Premise direct $^{\mathrm{TMI}}$ & $6.088 \pm 0.064$ & $3.152 \pm 0.063$ & $1.033 \pm 0.281$ & $34.182 \pm 8.865$ \\
\hline Premise indirect $^{\mathrm{TM}}$ & $6.136 \pm 0.051$ & $3.106 \pm 0.099$ & $1.160 \pm 0.125$ & $38.641 \pm 5.346$ \\
\hline
\end{tabular}

DTS was the highest for Ceramage ${ }^{\circledR}$ microfilled hybrid material (39.21 MPa). DTS are directly linear with the ones obtained for HV. Visuttiwattanakorn and co. evaluated DTS in aluminium oxide coated Ceramage ${ }^{\circledR}$ and SR Nexco (Ivoclar Vivadent, Schaan, Liechtenstein) composites [28]. Their research showed higher DTS values compared to our study, due to the fact that composite metallic coating leads to increased material properties. Interestingly, Ceramages ${ }^{\circledR}$, DTS had lower values from those given by the manufacturer - $146 \mathrm{MPa}[29]$. Fernandez et al. assessed DTS in Gradia ${ }^{\circledR}$ and Ceramage ${ }^{\circledR}$ materials, but their result do not correspond to the ones in Table 4, being lower with $20 \mathrm{MPa}$ for Ceramage ${ }^{\circledR}$ and 4 MPa for Gradia ${ }^{\circledR}$ [30]. As for Premise direct $^{\mathrm{TM}}$ and indirect ${ }^{\mathrm{TM}}$, DTS values were lower than those obtained by Malta and co., Moraes and co. [26, 31]. CS and DTS were correlated in literature studies and it was evidenced there is a correlation between the two properties; it has been reported that DTS and $\mathrm{CS}$ are higher in nanofilled composited compared cu microfilled ones, and the explanations is given by the degree of filler loading $[31,32]$. However, our analysis showed the opposite. Dall'Oca evaluated by 
means of SEM Gradia ${ }^{\circledR}$ elements' structure and he noticed the presence of voids in the matrix, which might represent stress areas and an etiological factor for mechanical deficiency [33].

\subsection{Water absorption (Wsp)}

Data regarding Wsp is presented in Table 5. Wsp coefficient had a linear ascending coefficient until day 7. Between day 7 and 8 there was a decrease in Wsp, after which the ascending trend resumed. Wsp varied among the composites as follows (presented in ascending sequence):

- Day 1: Ceramage ${ }^{\circledR}<$ Premise indirect ${ }^{\mathbf{T M}}<$ Gradia $^{\circledR}<$ Premise direct $^{\mathbf{T M}}$

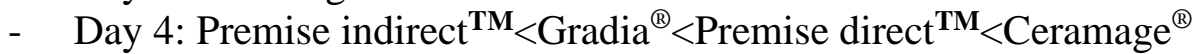

- $\quad$ Day 6: Premise indirect ${ }^{\mathrm{TM}}<$ Premise direct ${ }^{\mathrm{TM}}<$ Gradia $^{\circledR}<$ Ceramage $^{\circledR}$

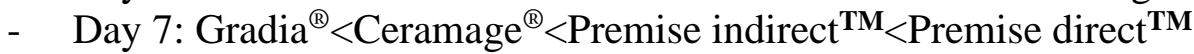

- $\quad$ Day 8: Premise indirect ${ }^{\mathbf{T M}}<$ Gradia $^{\circledR}<$ Ceramage $^{\circledR}<$ Premise direct $^{\mathbf{T M}}$

- Day 31: Ceramage ${ }^{\circledR}<$ Premise indirect ${ }^{\mathbf{T M}}<$ Gradia $^{\circledR}<$ Premise $\operatorname{direct}^{\mathbf{T M}}$.

Table 5. Wsp evaluation - Mean and SD

\begin{tabular}{|c|c|c|c|c|}
\hline \multirow{2}{*}{ Variable $(\mathrm{N}=3)$} & \multicolumn{4}{|c|}{ Wsp - Mean \pm SD } \\
\hline & Premise indirect ${ }^{\mathrm{TM}}$ & Gradia $^{2}$ & Ceramage $^{2}$ & Premise direct ${ }^{\mathrm{TM}}$ \\
\hline Day $1 \mu \mathrm{g} / \mathrm{mm}^{3}$ & $4.340 \pm 1.729$ & $6.982 \pm 3.118$ & $3.208 \pm 0.864$ & $7.737 \pm 1.819$ \\
\hline Day $4 \mu \mathrm{g} / \mathrm{mm}^{3}$ & $3.774 \pm 1.729$ & $4.906 \pm 0.864$ & $8.870=0.653$ & $5.661 \pm 0.566$ \\
\hline Day $6 \mu \mathrm{g} / \mathrm{mm}^{3}$ & $3.397 \pm 1.961$ & $6.794 \pm 2.995$ & $8.115=4.397$ & $5.284 \pm 0.326$ \\
\hline Day $7 \mu \mathrm{g} / \mathrm{mm}^{3}$ & $6.982 \pm 2.552$ & $6.039 \pm 1.178$ & $6.605=1.729$ & $10.379 \pm 5.260$ \\
\hline Day $8 \mu \mathrm{g} / \mathrm{mm}^{3}$ & $5.473 \pm 1.424$ & $5.661 \pm 0.980$ & $5.850=1.424$ & $9.247 \pm 3.769$ \\
\hline Day $31 \mu \mathrm{g} / \mathrm{mm}^{3}$ & $8.870 \pm 4.611$ & $9.813 \pm 2.792$ & $8.492=2.264$ & $13.021 \pm 1.497$ \\
\hline
\end{tabular}

There was a significant statistic difference $(\mathrm{p}=0.002)$ between all composite categories at day 4 . No other differences were found for Wsp evaluation.

Water absorption and solubility were determined because dental materials are continuously undergone to humid medium - saliva, to which are added hydration and liquid nutrients. In the present study, the absorption relations were not linear. The maximum degree of Wsp was recorded for all materials in the first week of the immersion, results which are in accord to the literature [34-36].We found a statistically significant correlation between the four composites in day 4 ( $\mathrm{p}=0.002)$, and in day 8 all samples presented a reduction in water absorption degree, which afterwards increased from day 9. Premises' Wsp for day 1 and 7 are similar to the ones resulted from Moraes study $-5.1 \mu \mathrm{g} / \mathrm{mm}^{3}$ [31]. Wei and co. weight differences for Gradia ${ }^{\circledR}$ anterior and posterior, after 150 days of distilled water immersion [37]. They noticed a linear weight-time increase by $1.92 \%$ and $0.74 \%$ hygroscopic expansion. Bociong had for Gradia ${ }^{\circledR} 35 \mu \mathrm{g} / \mathrm{mm}^{3} \mathrm{Wsp}$, after 57 days of water immersion [38], result which after the time adjustment is in disagreement with ours. Although Gradias ${ }^{\circledR}, 31$ days Wsp was $5.66 \mu \mathrm{g} / \mathrm{mm}^{3}$, it is less likely for it to increase 10 folds in the next three weeks. The primal factor that influences water absorption is the main monomer, more specifically its affinity for water molecules, corelated with the degree of conversion and hydrophilic bonds; other factor are the water contact area, type of filler and particles' dimension (as much it increases the filler percentage, the monomer percentage is reduced and along with it also the absorption capacity), curing initiator and catalyst [39]. Hydrophobic monomers, such as UDMA, siloxane, form rigid bonds which reduce the polymer chains alteration, inhibiting water diffusion, as it's known the monomers' hydrophilic scale: TEGMA>Bis-GMA>UDMA>Bis-EMA [40, 41]. Considering the monomers' characteristics, Wsp should have the following relation to the tested composites: Ceramage ${ }^{\circledR} /$ Gradia $^{\circledR}>$ Premise direct $^{\mathrm{TM}}>$ Premise indirect $^{\mathrm{TM}}$. Although it has UDMA as main monomer, precured filler and silica dioxide composition, Gradia ${ }^{\circledR}$ showed the lowest Wsp only in day 7 , in the rest of the evaluated stages being the second either the third. Overall, Premise direct ${ }^{\mathrm{TM}}$ had the highest Wsp and Ceramage ${ }^{\circledR}$ the lowest. We consider that Gradia ${ }^{\circledR}$ had a higher Wsp compared to Ceramage $^{\circledR}$ due to the precured fibers, which could increase the composites' hydrophilic character, 
compared to $\mathrm{Zr}$ silicate (which is known to be hydrophobic). It was surprisingly to see that our study rejected the literature hypothesis according to which along with the increase of filler percentage and decrease in particles dimension, diminishes Wsp, by limitation of intermolecular spaces.

\subsection{Water solubility (SL)}

Results from SL evaluation are shown in Table 6 and Figure 2. Regarding composites' solubility, there was an ascending trend of the solubility up to day 7 . Between day 7 and 8 , it was observed a decrease in sorption. From day 8 to 31, the SL values continued on an ascending slope. SL varied among the composites as follows (presented in descending sequence):

- $\quad$ Day 1: Premise indirect ${ }^{\mathbf{T M}}<$ Premise direct ${ }^{\mathrm{TM}}<$ Gradia $^{\circledR}<$ Ceramage $^{\circledR}$

- $\quad$ Day 4: Premise indirect ${ }^{\text {TM }}<$ Premise direct ${ }^{\text {TM }}<$ Gradia $^{\circledR}<$ Ceramage $^{\circledR}$

- $\quad$ Day 6: Premise direct ${ }^{\mathbf{T M}}<$ Premise indirect ${ }^{\mathbf{T M}}<$ Gradia $^{\circledR}<$ Ceramage $^{\circledR}$

- Day 7: Premise indirect ${ }^{\mathbf{T M}}<$ Premise direct ${ }^{\mathbf{T M}}<$ Gradia $^{\circledR}<$ Ceramage $^{\circledR}$

- Day 8: Premise direct ${ }^{\mathbf{T M}}<$ Premise indirect ${ }^{\mathbf{T M}}<$ Gradia $^{\circledR}<$ Ceramage $^{\circledR}$

- $\quad$ Day 31: Premise indirect ${ }^{\mathbf{T M}}<$ Premise direct $^{\mathbf{T M}}<$ Ceramage $^{\circledR}<$ Gradia $^{\circledR}$.

Table 6. Water SL-Mean and SD

\begin{tabular}{|c|c|c|c|c|}
\hline \multirow{2}{*}{ Variable $(\mathrm{N}=3)$} & \multicolumn{4}{|c|}{ SL - Mean \pm SD } \\
\hline & Premise indirect ${ }^{\mathrm{TM}}$ & Gradia $^{2}$ & Ceramage $^{*}$ & Premise direct \\
\hline Day $1 \mu \mathrm{g} / \mathrm{mm}^{3}$ & $-3.208 \pm 0.326$ & $-6.227 \pm 1.497$ & $-7.171 \pm 0.864$ & $-4.340 \pm 0.864$ \\
\hline Day $4 \mu \mathrm{g} / \mathrm{mm}^{3}$ & $-6.982 \pm 0.326$ & $-13.965 \pm 1.729$ & $-14.909 \pm 0.653$ & $-7.548 \pm 0.326$ \\
\hline Day $6 \mu \mathrm{g} / \mathrm{mm}^{3}$ & -10.191 & $-20.193 \pm 1.729$ & $-21.137 \pm 0.326$ & $-10.002 \pm 0.653$ \\
\hline Day $7 \mu \mathrm{g} / \mathrm{mm}^{3}$ & -10.002 & $-21.703 \pm 1.819$ & $-22.646 \pm 1.132$ & $-10.002 \pm 0.864$ \\
\hline Day $8 \mu \mathrm{g} / \mathrm{mm}^{3}$ & $-9.624 \pm 2.041$ & $-20.948 \pm 1.698$ & $-21.514 \pm 1.497$ & $-9.436 \pm 1.988$ \\
\hline Day $31 \mu \mathrm{g} / \mathrm{mm}^{3}$ & $-12.833 \pm 0.326$ & $-32.083 \pm 4.611$ & $-30.950 \pm 3.268$ & $-23.024 \pm 9.450$ \\
\hline
\end{tabular}

We found a highly statistically significant difference $(\mathrm{p}<0.001)$ between the tested composite groups in day 4, 6, 7, 8 and 31. Posthoc analysis analysis evidenced a medium intensity direct correlation $(\mathrm{p}=0.005)$ of SL between Premise indirect ${ }^{\mathrm{TM}}$ compared to Ceramage $^{\circledR}$. In day 4, 6, 7, 8 there was a highly statistically significant difference $(\mathrm{p}<0.001)$ between Premise indirect ${ }^{\mathrm{TM}}$, Gradia ${ }^{\circledR}$ and Ceramage ${ }^{\circledR}$, and between Gradia $^{\circledR}$ and Premise direct $^{\mathrm{TM}}(\mathrm{p}<0.001)$. Last evaluation showed a highly statistically significant difference $(\mathrm{p}=0.001)$ between Premise $\operatorname{direct}^{\mathrm{TM}}$, Gradia ${ }^{\circledR}$, Ceramage ${ }^{\circledR}$, a statistically significant difference between Gradia ${ }^{\circledR}$ and Premise direct ${ }^{\mathrm{TM}}(\mathrm{p}=0.002)$ and between Ceramage ${ }^{\circledR}$ and Premise direct ${ }^{\mathrm{TM}}$. There was an indirect significant correlation between Wsp and SL in day $4(\mathrm{r}=-0.579$, $\mathrm{p}=0.049)$.

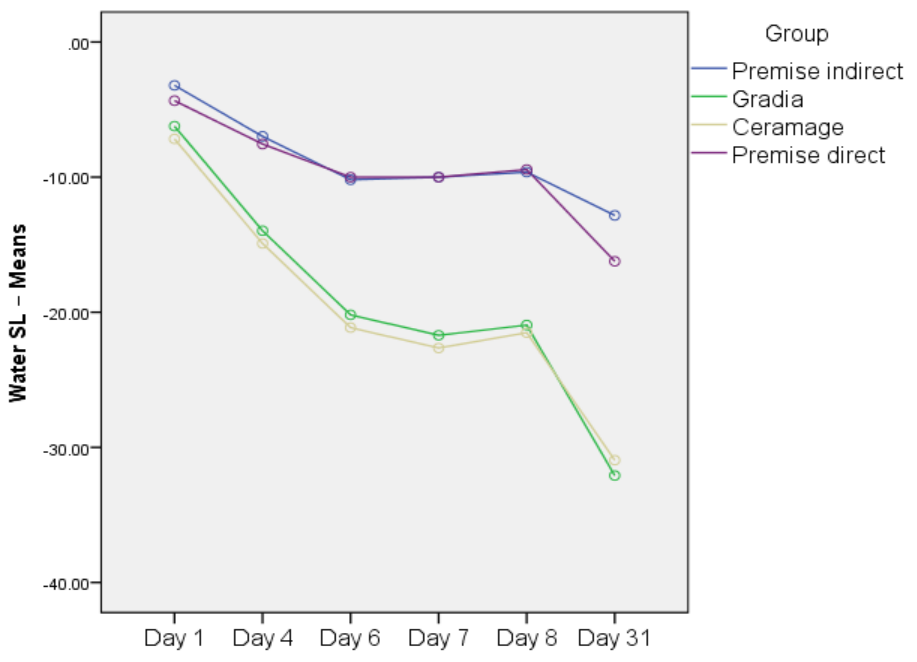

Figure 2. Water SL evolution between measurements

Factors which influence composite SL are similar to Wsp ones, the higher the filler molecules and $\mathrm{C}=\mathrm{C}$ cross-link bonds of hydrophobic monomers, the lower SL will be [42]. The 31's day evaluation showed that overall, the highest SL was stated for Gradia ${ }^{\circledR}$ ( $\operatorname{similar}$ to Ceramage ${ }^{\circledR}$ ) and the lowest for 
Premise indirect ${ }^{\mathrm{TM}}$. Statistical analysis showed a positive high correlation for days 4, 6, 7, 8 between the tested samples. From day 1 to day 4 SL had doubled for all composites, and between day 7 and 8 we noticed a linear reduction of SL degree, which rearranged ascending from day 9 to 31, which was similar to Wsp trajectory. Our $24 \mathrm{~h}$ results are closely to Misilli [43]. Monomer molecular dimension also represent an important factor in composite SL, such that small and mobile molecules -TEGDMA will dissociate faster compared to big molecules with less cross-ling bonds - Bis-GMA [43]. In our study, composites which had in the organic matrix Bis-GMA associated to TEGDMA had the lowest SL, but with a close value to the ones which had Bis-GMA monomer. Surprisingly, UDMA-hydrophobic microhybrid composite had SL twice the value compared to the ones TEGDMA/Bis-GMA based, although in the literature there are results regarding its SL $\left(23.85 \mu \mathrm{g} / \mathrm{mm}^{3}\right)$, and its property of creating intermolecular hydrogen cross-links between uretan species [44]. Maybe due to the increased dimension of the filler particles $(85 \mu \mathrm{m})$ the intermolecular spaces might allow water molecules access and through chemical reaction to remove $-\mathrm{OH}$ and initiate composite degradation.

One of the study's limitation was the in vitro evaluation conditions, which could not be the functional replica of the oral cavity structures. Another deficiency was the lack of comparative literature study regarding microhybrid Ceramage ${ }^{\circledR}$ and Gradia ${ }^{\circledR}$ composite Wsp and SL.

\section{Conclusions}

Taking into account the limitations of our study, we can consider that composite parameters influence their mechanical properties. Thus, we have demonstrated that microfilled hybrid composites UDMAbased monomer had the highest evaluations regarding Vickers microhardness, compressive strenght and tensile strenght, whereas water absorption was the highest for nanofilled hybrid Bis-GMA/TEGDMA, and solubility for microfilled hybrid UDMA based monomer. Future studies will have to focus on the association of the benefits of organic matrix and fillers of the two composite materials, to approach to a novel technique which will produce sustainable dental restoration composites, under the multifactorial action of oral cavity structure.

Acknowledgments: This study was supported by "Iuliu Haţieganu" University of Medicine and Pharmacy Cluj-Napoca, PhD grant 3791/01.10.2014 and partially by COFUND-ERA-HDHL ERANET Project, European and International Cooperation - Subprogram 3.2 - Horizon 2020, PNCDI III Program - Biomarkers for Nutrition and Health - "Innovative technological approaches for validation of salivary AGEs as novel biomarkers in evaluation of risk factors in diet-related diseases", grant no 25/01.09.2017.

\section{References}

1. FISHER, J., VARENNE, B., NARVAEZ, D., VICKERS, C., The Minamata Convention and the phase down of dental amalgam, World Heal. Organ., 96(6), 2018, 436-438.

2.ALSHABIB, A., SILIKAS, N., WATTS, D.C., Hardness and fracture toughness of resin-composite materials with and without fibers, Dent. Mater., 35(8), 2019, 1194-1203.

3. CK HO, C.K.C., Composite artistry using Premise-The new breed of nanofiller, Dent. Pract., 5(2), 2004, 138-142.

4.BLACKHAM, J.T., VANDEWALLE, K.S., LIEN, W., Properties of hybrid resin composite systems containing prepolymerized filler particles, Oper. Dent,. 34(6), 2009, 697-702.

5. FERRACANE, J., Current trends in dental composites, Crit. Rev. Oral Biol. Med., 6(4), 1995, 302218.

6.HERVÁS-GARCÍA， A., MARTÍNEZ-LOZANO, M.A., CABANES-VILA， J., BARJAUESCRIBANO, A., FOS-GALVE, P., Composite resins. A review of the materials and clinical indications, Med. Oral Patol. Oral Cir. Bucal., 11(2), 2006, 215-220.

7.BRAGA, R., BALLESTER, R., FERRACANE, J., Factors involved in the development of polymerization shrinkage in resin-composites. A systematic review, Dent Mater., 21, 2005, 962-970. 
8.***Premise technical information. URL: https://www.kerrdental.com/kerr-restoratives/premiseuniversal-nanofilled-composite (accessed 10 June 2020)

9. Ceramage Technical Information. URL: https://www.shofu.de/en/produkt/ceramage-uk/ (accessed 10 June 2020)

10. SOANCǍ, A., ROMAN, A., MOLDOVAN, M., PERHAITA, I., TUDORAN, L.B., ROMÎNU, M, Study on thermal behaviour, structure and filler morphology of some indirect composite resins, Dig. J. Nanomater. Biostructures., 7(3), 2012, 1071-1081.

11.*** ADA, Reports of Council and Bureau, 7, 1977, sp. 27.

12. BASTING, R.T., SERRA, M.C., RODRIGUES, A.L., In situ microhardness evaluation of glassionomer/composite resin hybrid materials at different post-irradiation times, J. Oral Rehabil., 29(12), 2002, 1187-1195.

13. OZCAN, S., YIKILGAN, I., UCTASLI, M.B., BALA, O., KURKLU, Z.G.B., Comparison of timedependent changes in the surface hardness of different composite resins, Eur. J. Dent., 7(5 SUPPL.), 2013.

14. RASTELLI, A.N.S., JACOMASSI, D.P., FALONI, A.P.S., et al., The filler content of the dental composite resins and their influence on different properties, Microsc. Res. Tech. 75(6), 2012, 758-765. 15. PETROPOULOU, A., DIMITRIADI, M., ZINELIS, S., SARAFIANOU, A., Surface Characteristics and Color Stability of Composites, 13(11), 2020, 2540.

16. ENGELHARDT, F., HAHNEL, S., PREIS, V., ROSENTRITT, M., Comparison of flowable bulkfill and flowable resin-based composites: an in vitro analysis, Clin. Oral Investig., 20(8), 2016, 2123 2130.

17. BURUIANA, T., BURUIANA, E., MELINTE, V., MOLDOVAN, A., Urethane dimethacrylate oligomers for dental composite matrix: Synthesis and properties, Polym. Eng. Sci., 49(6), 2009, $1127-$ 1135 .

18. MOLDOVAN, M., BALAZSI, R., SOANCA, A., et al., Evaluation of the degree of conversion, residual monomers and mechanical properties of some light-cured dental resin composites, Materials (Basel), 12(13), 2019, 1-14.

19. GAJEWSKI, V., PFEIFER, C., FROES-SALGADO, N., BOARO, I., BRAGA, R.. Monomers used in resin composites. Degree of conversion, mechanical properties and water sorption/solubility, Braz Dent., 40(23), 2012, 508-514.

20. LIN, J., SUN, M., ZHENG, Z., et al., Effects of rotating fatigue on the mechanical properties of microhybrid and nanofiller-containing composites, Dent. Mater. J., 32(3), 2013, 476-483.

21. SHAHDAD, S.A., MCCABE, J.F., BULL, S., RUSBY, S., WASSELL, R.W., Hardness measured with traditional Vickers and Martens hardness methods, Dent. Mater., 23(9), 2007, 1079-1085.

22. KYO-HAN, K., JOO, L., OSAMU, O., The effect of filler loading and morphology on the mechanical properties of contemporary composites, J. Prosthet. Dent., 87(6), 642-649.

23. NASCIMENTO, A.S., LIMA, D.B., FOOK, M.V.L., et al., Physicomechanical characterization and biological evaluation of bulk-fill composite resin, Braz. Oral Res., 32, 2018, 1-14.

24. RANDOLPH, L.D., PALIN, W.M., LELOUP, G., LEPRINCE, J.G., Filler characteristics of modern dental resin composites and their influence on physico-mechanical properties, Dent. Mater., 32(12), 2016, 1586-1599.

25. MOHARAM, L.M., EL-HOSHY, A.Z., ABOU-ELENEIN, K., The effect of different insertion techniques on the depth of cure and vickers surface micro-hardness of two bulk-fill resin composite materials, J. Clin. Exp. Dent., 9(2), 2017, e266-e271.

26. MAGNE, P., MALTA, D.A.M.P., ENCISO, R., MONTEIRO-JUNIOR, S., Heat treatment influences monomer conversion and bond strength of indirect composite resin restorations, J. Adhes. Dent., 17(6), 2015, 559-566.

27. ALKHUDHAIRY, F., VOHRA, F., Compressive strength and the effect of duration after photoactivation among dual-cure bulk fill composite core materials, Pakistan J. Med. Sci., 32(5), 2016, 11991203. 
28.VISUTTIWATTANAKORN, P., SUPUTTAMONGKOL, K., ANGKOONSIT, D., KAEWTHONG, S., CHAROONANAN, P., Microtensile bond strength of repaired indirect resin composite, J. Adv. Prosthodont., 9(1), 2017, 38-44.

29. LUNG, C., MATINLINNA, J., Aspects of silane coupling agents and surface conditioning in dentistry. an overview, Dent Mater., 28, 2012, 467-477.

30.FERNANDES, C.A., RIBEIRO, J.C., LARSON, B.S., et al. Microtensile bond strength of resinbased composites to Ti-6Al-4V, Dent. Mater., 25(5), 2009, 655-661.

31. de MORAES, R., de GONCALVES L.S., LANCELLOTTI, A., CONSANI, S., CORRERSOBRINHO, L., SINHORETI, M., Nanohybrid resin composites. Nanofiller loaded materials or traditional microhybrid resins?, Oper. Dent., 34(5), 2009, 551-557.

32.ALZRAIKAT, H., BURROW, M.F., MAGHAIREH, G.A., TAHA, N.A., Nanofilled resin composite properties and clinical performance: A review, Oper. Dent., 43(4), 2018, E173-E190.

33. DALL'OCA, S., PAPACCHINI, F., RADOVIC, I., POLIMENI, A., FERRARI, M., Repair potential of a laboratory-processed nano-hybrid resin composite, J. Oral Sci., 50(4), 2008, 403-412.

34. KEYF, F., YALCIN, F., The weight change of various light-cured restorative materials stored in water, J. Contemp. Dent. Pract., 6(2), 2005, 72-79.

35. HEDGE, M., BIRADAR, B., Evaluation of weight change of three different light cured composite restorative materials stored in water, J. Conserv. Dent., 13, 2008, 109-114.

36. KNOBLOCH, L., KERBY, R., MCMILLEN, K., CLELLAND, N., Solubility and sorption of resinbased luting cements, Oper. Dent., 25(5), 2000, 434-440.

37.WEI, Y.J., SILIKAS, N., ZHANG, Z.T., WATTS, D.C., The relationship between cyclic hygroscopic dimensional changes and water sorption/desorption of self-adhering and new resin-matrix composites, Dent. Mater., 29(9), 2013, e218-e226.

38. BOCIONG, K., SZCZESIO, A., SOKOLOWSKI, K., et al., The influence of water sorption of dental light-cured composites on shrinkage stress, Materials (Basel), 2017, 10(10), 1142.

39. FERRACANE, J., Hygroscopic and hydrolytic effects in dental polymer networks, Dent Mater., 22, 2006, 211-222.

40. MARGHALANI, H., Sorption and solubility characteristics of self-adhesive resin cements, Dent Mater., 28, 2012, e187-198.

41. FERRACANE, J., PALIN, W., Effects of particulate filler systems on the properties and performance of dental polymer composites. In: Non-metalic biomaterials for tooth repair and replacement, Elsevier Inc, Ansterdam, the Netherlands, 2012.

42. BIRADAR, B., BIRADAR, S., ARVIND, M.S., Evaluation of the effect of water on three different light cured composite restorative materials stored in water: An in vitro study, Int. J. Dent., 2012, e640942.

43. MISILLI, T., GÖNÜLOL, N., Water sorption and solubility of bulk-fill composites polymerized with a third generation LED LCU, Braz. Oral Res., 31, 2017, e80.

44. TANAKA, K., TAIRA, M., SHINTANI, H., WAKASA, K., YAMAKI, M., Residual monomers (TEGDMA and Bis-GMA) of a set visible-light-cured dental composite resin when immersed in water, J Oral Rehab., 18(4), 1991, 353-362. 